\title{
Signs of Multilingualism at Religious Places in Surabaya: A Linguistic Landscape Study
}

\author{
Ali Wafa, Universitas Airlangga \\ Sheila Wijayanti, Universitas Airlangga
}

\begin{abstract}
This paper aims to present the languages used as public signs at the places of worship in Surabaya. The area is selected for its multilingual society. The data is in the forms of photos of outdoor and indoor signs and is taken from ten outstanding religious places in the city namely two mosques, two churches, two Chinese temples (klenteng), two Hindu temples (pura), and two Buddhist temples (vihara). Three hundred and eighty six public signs are collected. As stated by Landry and Bourhis (1997) the collected data is then analyzed based on the landscape linguistic theory. The results demonstrate that the languages as public signs found in the ten places of worship vary, i.e., Indonesian, Balinese, Javanese, Madurese, Malay, English, Chinese, Arabic, Pāli language, Latin language, German, French, Dutch and Japanese. However, Indonesian remains the most used language at mosques, churches, and Buddhist temples. However, Chinese language is the most frequently used at Chinese temples. Meanwhile, Indonesian and Balinese language almost have the same position at Hindu temples.
\end{abstract}

Keywords: buddhist temples; chinese temples; churches; hindu temples; linguistic landscape; mosques; multilingualism

\section{Introduction}

Surabaya, like other cities in the world, has developed and become center of business and economic activities in East Java. As a result, many people from different regions and countries come and live in the city. Surabaya goverment (www.surabaya.go.id/berita/8228-demografi) mentions it as follows:

"Various ethnic groups exist in the city of Surabaya, such as Malays, Chinese, Indians, Arabs, and Europeans. Ethnic archipelago can be found such as Madura, Sunda, Batak, Kalimantan, Bali, Sulawesi that blend with the natives form a cultural pluralism which later became the hallmark of the city of Surabaya".

The interaction among the diverse ethnic groups creates a multilingual society. Wardhaugh (2015: 83) uses the term multilingual to refer generally to situations in which there are speakers of more than one language. It not only occurs in spoken context but also in written signs. People all live in places surrounded by written signs, which are displayed on street names, posters, advertisements, official notices and messages, etc (Xia \& Li, 2016). Written signs of multilingualism in Surabaya can be easily found at very welkown places of worship that function as religious destination. It probably attracts many people from different ethnicities, regions, and countries, and religions come to visit in such religious destination. In addition, the track of multilingual society can be noticed from language use. As a result, there may be used more than one language as public signs.

This paper aims at analyzing signs of multilingualism at religious places in Surabaya. The purposes are to discover languages as public signs at ten outstanding places of worship in Surabaya and to show the most used language in all the religious places.

\section{Theoretical framework}

The approach of this paper is landscape linguistic. Landry and Bourhis defined landscape linguistic as follows: 
"Language of public road sign, advertising bilboards, street names, place names, commercial shop signs, and publics signs on government building [which] combines to form the linguistic landscape of a given territory, region, or agglomeration ${ }^{\text {ee }}(1997: 25)$.

Ben-Rafael et.al (2006: 14) defined the linguistic landscape as referring to any sign announcement located outside or inside a public institution or a private business in a given geographical location. Gorter (2006) categorized signs either top-down (official signs issued by public bureaucracies) or bottom-up (non-official signs posted by individuals or businesses). The main difference between these two wide categories of LL elements resides in the fact that the former are expected to reflect a general commitment to the dominant culture while the latter are designed much more freely according to individual strategies (Ben-Rafael, 2006: 8). Thus, public signs at places of worship can be categorised as top-down signs because they are part of religious institution.

There have been two related studies associated with this paper. Firstly was conducted by Coluzzi and Kitade (2015) entitled the languages of places of worship in the Kuala Lumpur area: a study on the religious linguistic landscape in Malaysia. Secondly was done by Intan Novita Ferdiyanti (2016) entitled multilingualisme dalam lanskap linguistik di wilayah kota Surabaya (multilingualism on landscape linguistic in the city of Surabaya). Thus, such research is never conducted in Surabaya.

\section{Methodology}

The method of this study is qualitative. The data are three hundred and eighty six written signs in the form of photos inside and outside the ten outstanding religious places in Surabaya. According to Siti Nur Syamsiyah, head of culture and tourism office Surabaya (2018), the terms 'outstanding religious places in Surabaya' includes (1) the building is a cultural heritage in Surabaya, (2) big and large, and (3) used as religious destination. The ten famous places of worship in Surabaya, according to culture and tourism office Surabaya, are Ampel mosque, Al Akbar National mosque, Kelahiran Santa Perawan Maria church, Katedral Hati Kudus Yesus church, Agung Jagat Karana Hindu temple, Segara Hindu temple, Budhayana Buddhist temple, Sanggar Agung Buddhist temple, Hok An Kiong Chinese temple, and Boen Bio Chinese temple.

\section{Findings}

\subsection{Lanscape linguistic at Mosques}

Table 1: Mosques

\begin{tabular}{|c|c|c|c|c|c|}
\hline $\begin{array}{l}\mathbf{N} \\
\mathbf{0}\end{array}$ & \multicolumn{2}{|r|}{ Languages } & \multirow{2}{*}{$\begin{array}{c}\text { Ampe } \\
\mathbf{l} \\
\text { Mosq } \\
\text { ue }\end{array}$} & \multirow{2}{*}{$\begin{array}{c}\text { Al } \\
\text { Akbar } \\
\text { Nation } \\
\text { al } \\
\text { Mosqu } \\
\text { e } \\
35\end{array}$} & \multirow{2}{*}{$\begin{array}{c}\text { Amou } \\
\mathbf{n t}\end{array}$} \\
\hline \multirow{2}{*}{1} & \multirow{2}{*}{$\begin{array}{l}\text { Monoling } \\
\text { ual }\end{array}$} & Indonesian & & & \\
\hline & & Arabic & 1 & 2 & 3 \\
\hline \multirow{2}{*}{2} & \multirow{2}{*}{ Bilingual } & Indonesian-English & 2 & 13 & 15 \\
\hline & & Indonesian-Arabic & 2 & 2 & 4 \\
\hline \multirow{3}{*}{3} & \multirow{3}{*}{$\begin{array}{l}\text { Multiling } \\
\text { ual }\end{array}$} & Indonesian-Arabic-English & 1 & - & 1 \\
\hline & & Indonesian-Arabic-Madurese-Javanese-Malay & 1 & - & 1 \\
\hline & & $\begin{array}{l}\text { Indonesian-English-German-French-Dutch-Chine } \\
\text { se-Japanese }\end{array}$ & 1 & - & 1 \\
\hline & & & 60 & 52 & 112 \\
\hline
\end{tabular}


As illustrated in Table 1, languages as public signs at the two mosques are Indonesian, Arabic, English, Madurese, Javanese, Malay, German, French, Dutch, Chinese, and Japanese. Indonesian (monolingual) is mostly used with eighty seven signs followed by Indonesian-English (bilingual) with fifteen signs. Meanwhile, Indonesian-Arabic (bilingual) and Arabic with four and three signs are less found. Multilinguals are the least used languages with one signs respectively..

Figure 1. An example of Indonesian sign

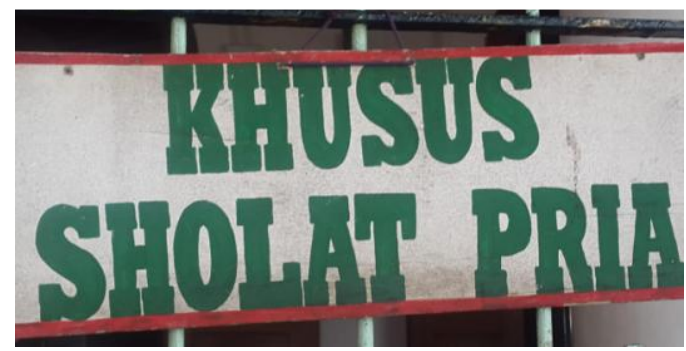

Figure 2. An example of Indonesian-English sign

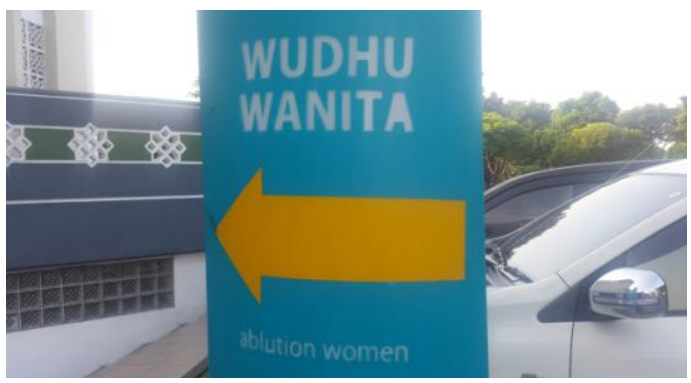

Figure 3. An example of

Indonesian-Arabic-Madurese-Javanese-Malay sign

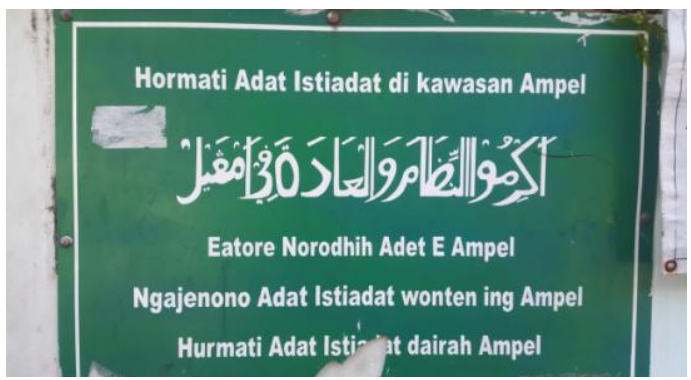

\subsection{Lanscape linguistic at Churches}

Table 2: Churches

\begin{tabular}{|c|c|l|c|c|c|}
\hline \multirow{2}{*}{ No } & \multicolumn{2}{|c|}{ Languages } & $\begin{array}{c}\text { Kelahiran } \\
\text { Santa Perawan } \\
\text { Maria Church }\end{array}$ & $\begin{array}{c}\text { Katedral Hati } \\
\text { Kudus Yesus } \\
\text { Church }\end{array}$ & Amount \\
\hline 1 & \multirow{2}{*}{ Monolingual } & Indonesian & 18 & 40 & 58 \\
\cline { 3 - 6 } & English & - & 1 & 1 \\
\hline 2 & Bilingual & Indonesian-English & 2 & - & 2 \\
\hline
\end{tabular}


Table 2, cont.

\begin{tabular}{|c|c|c|c|c|}
\hline & Indonesian-Latin & - & 3 & 3 \\
\hline & & 20 & 44 & 64 \\
\hline
\end{tabular}

As shown in Table 2, languages as public signs at the two churches are Indonesian, English, and Latin language. Indonesian (monolingual) is mostly used with fifty eight signs followed by Indonesian-Latin (bilingual) and Indonesian-English (bilingual) with three and two respectively. Meanwhile, English is the least with one sign.

Figure 4. An example of Indonesian sign

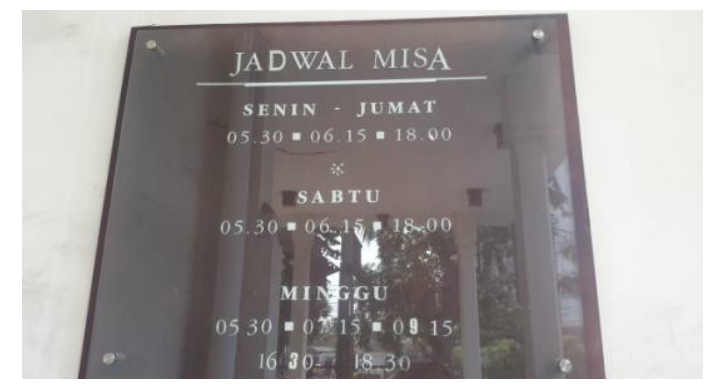

Figure 5. An example of Indonesian-English sign

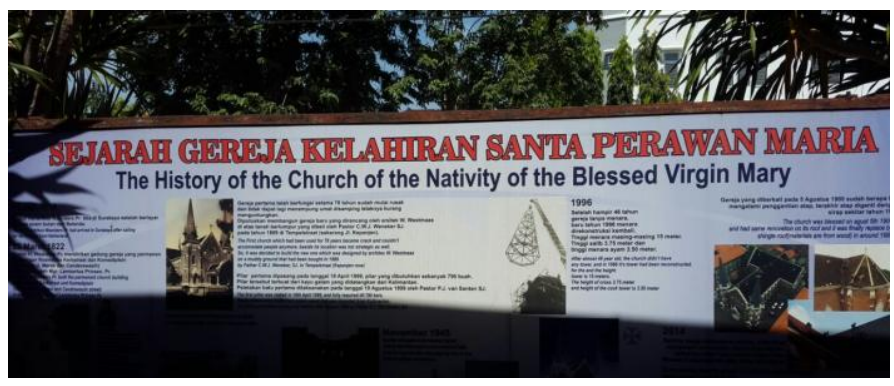

\subsection{Lanscape linguistic at Hindu temples}

Table 3: Pura (Hindu temples)

\begin{tabular}{|c|c|c|c|c|c|}
\hline No & \multicolumn{2}{|c|}{ Languages } & $\begin{array}{l}\text { Pura Agung } \\
\text { Jagat Karana }\end{array}$ & Pura Segara & Amount \\
\hline \multirow[t]{3}{*}{1} & \multirow{2}{*}{ Monolingual } & Indonesian & 9 & 7 & 16 \\
\hline & & Balinese & 10 & 1 & 11 \\
\hline & & English & - & 1 & 1 \\
\hline \multirow{2}{*}{2} & \multirow{2}{*}{ Bilingual } & Indonesian-English & - & 2 & 2 \\
\hline & & Indonesian-Balinese & 1 & 7 & 8 \\
\hline & & & 20 & 18 & 38 \\
\hline
\end{tabular}

In Table 3, demonstrates that languages as public signs at the two Hindu temples are Indonesian, Balinese, English, and Indonesian-English, and Indonesian-Balinese. Indonesian (monolingual) is mostly used with sixteen signs followed by Balinese (monolingual) and Indonesian-Balinese (bilingual) with eleven and eight signs. Meanwhile, Indonesian-English (bilingual) and English (monolingual) is the least with two and one signs respectively. 
Figure 6. An example of Indonesian sign

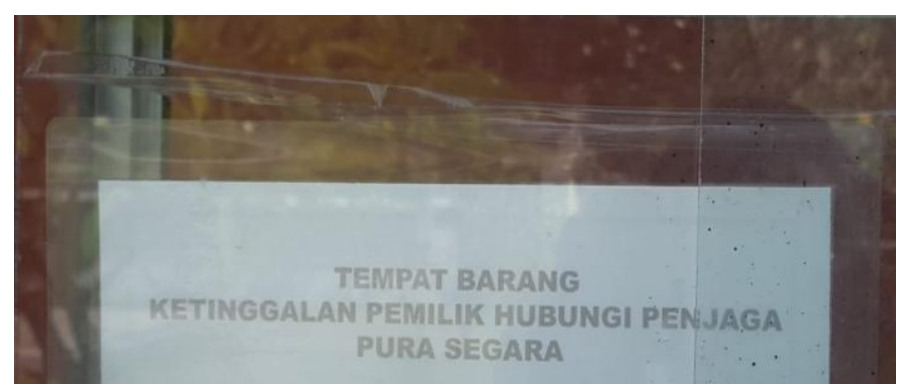

Figure 7. An example of Balinese sign

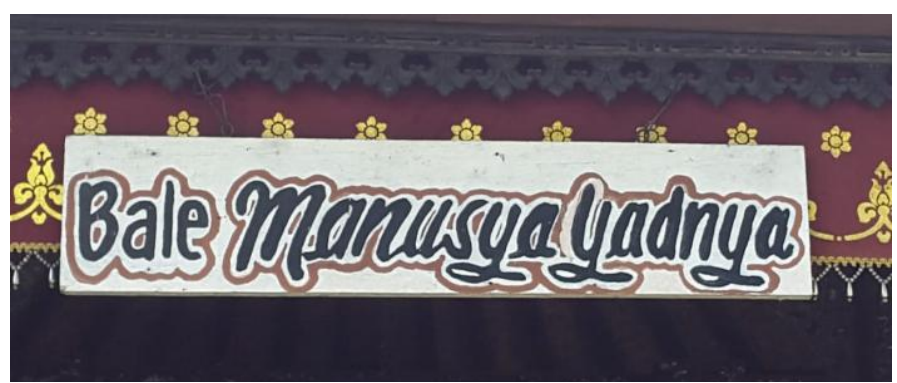

\subsection{Lanscape linguistic at Buddhist temples}

Table 4: Vihara (Buddhist temples)

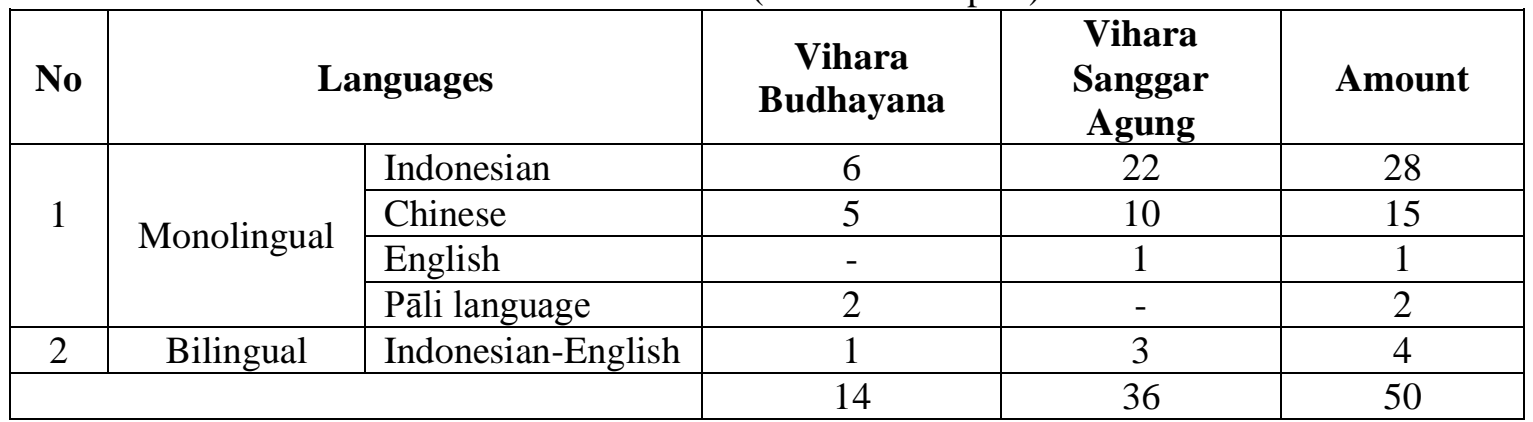

In Table 4, depicts that languages as public signs at the two Buddhist temples are Indonesian, Chinese, Pāli language and English. Indonesian (monolingual) is more frequently found with twenty eight signs followed by Chinese (monolingual) with fifteen signs. Indonesian-English (bilingual) and Pāli language (monolingual) appear with four and two signs. Meanwhile, English (monolingual) is the least with only one sign.

Figure 8. An example of Indonesian sign

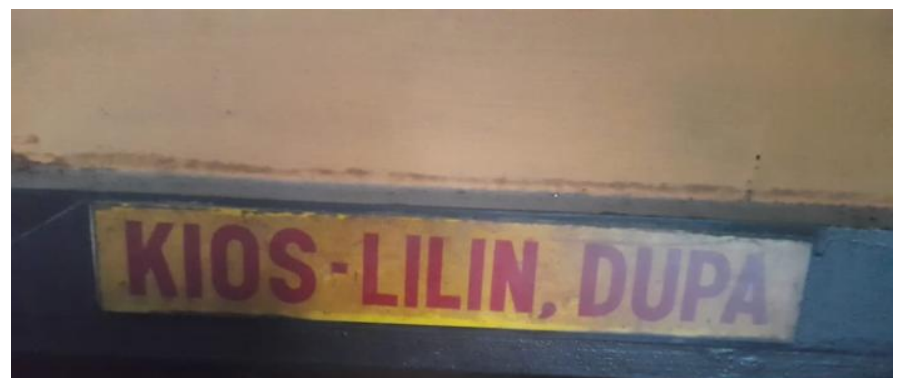


Figure 9. An example of Chinese sign

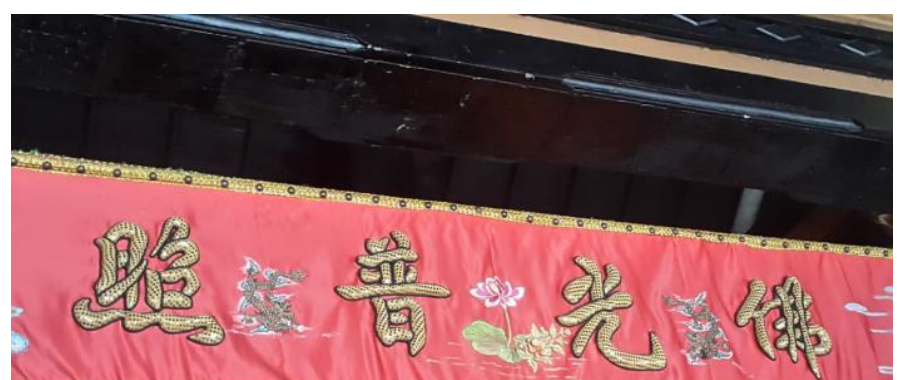

\subsection{Lanscape linguistic at Chinese temples}

Table 5: Klenteng (Chinese temples)

\begin{tabular}{|c|c|l|c|c|c|}
\hline \multirow{2}{*}{ No } & \multicolumn{2}{|c|}{ Languages } & $\begin{array}{c}\text { Klenteng } \\
\text { Hok An } \\
\text { Kiong }\end{array}$ & $\begin{array}{c}\text { Klenteng } \\
\text { Boen Bio }\end{array}$ & Amount \\
\hline \multirow{2}{*}{1} & \multirow{2}{*}{ Monolingual } & Indonesian & 6 & 11 & 17 \\
\cline { 3 - 6 } & Chinese & 47 & 50 & 97 \\
\hline \multirow{2}{*}{2} & \multirow{2}{*}{ Bilingual } & Indonesian-English & - & 3 & 3 \\
\cline { 3 - 6 } & Indonesian-Chinese & 4 & - & 4 \\
\hline \multicolumn{2}{|l|}{ Multilingual } & Indonesian-Chinese-English & - & 1 & 1 \\
\hline \multicolumn{2}{|r}{} & 57 & 65 & 122 \\
\hline
\end{tabular}

In Table 5, depicts that languages as public signs at the two Chinese temples are Chinese, Indonesian, and English. Chinese is often seen with fifty signs followed by Indonesian with eleven signs. Indonesian-Chinese and Indonesian-English (bilingual) less appear with four and three signs. Meanwhile, Indonesian-Chinese-English (multilingual) is the least with only one sign.

Figure 10. An example of Chinese sign

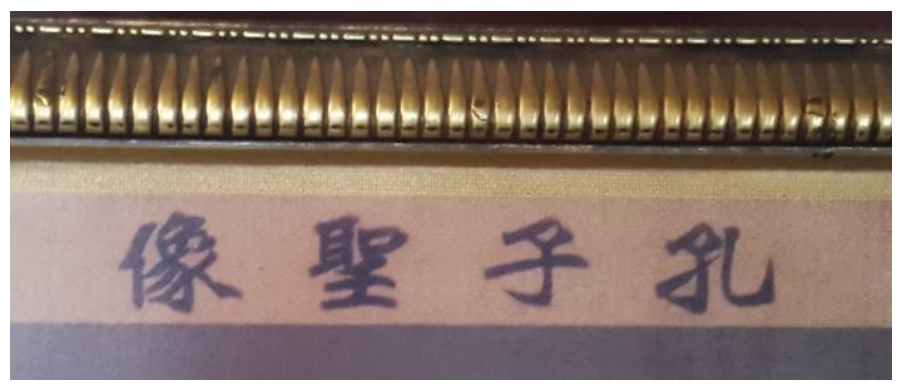

Figure 11. An example of Indonesian sign

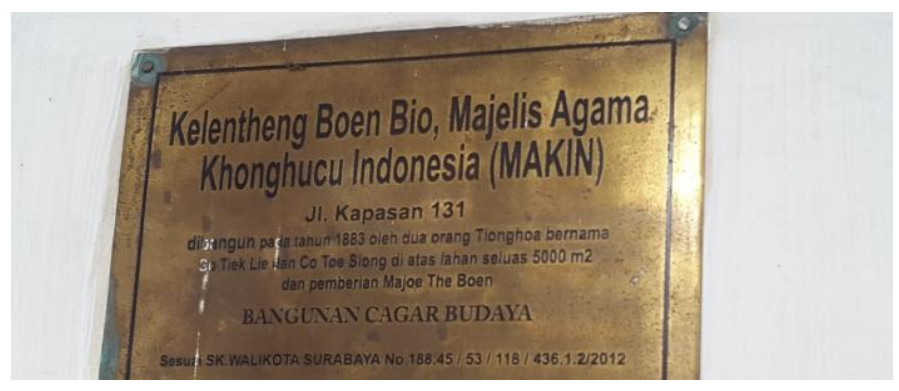


Figure 12. An example of Indonesian-Chinese sign

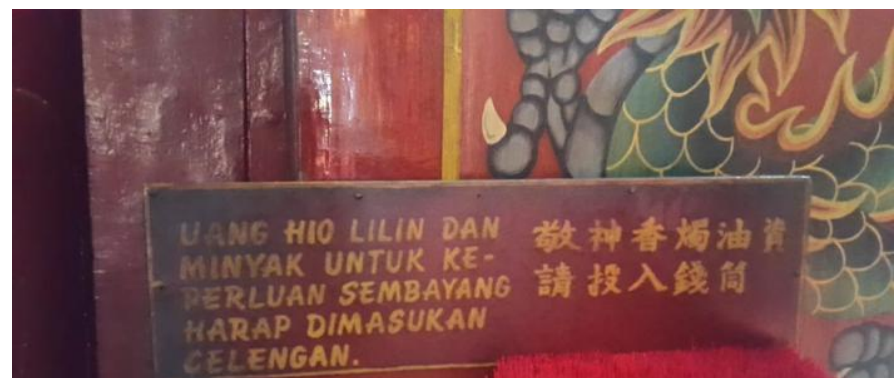

\subsection{Lanscape linguistic at ten religious places}

Table 6: Ten famous religious places

\begin{tabular}{|c|c|c|c|c|c|c|}
\hline No & Languages & Mosques & Churches & Pura & Vihara & Klenteng \\
\hline 1 & Indonesian & 87 & 58 & 16 & 28 & 17 \\
\hline 2 & Balinese & - & - & 11 & - & - \\
\hline 3 & English & - & 1 & 1 & 1 & - \\
\hline 4 & Chinese & - & - & - & 15 & 97 \\
\hline 5 & Arabic & 3 & - & - & & - \\
\hline 6 & Pāli language & - & - & - & 2 & - \\
\hline 7 & Indonesian-Balinese & & & 8 & - & - \\
\hline 8 & Indonesian-English & 15 & 2 & 2 & 4 & 3 \\
\hline 9 & Indonesian-Arabic & 4 & - & - & - & - \\
\hline 10 & Indonesian-Chinese & & & - & - & 4 \\
\hline 11 & Indonesian-Latin & - & 3 & - & - & - \\
\hline 12 & $\begin{array}{l}\text { Indonesian-Arabic-E } \\
\text { nglish }\end{array}$ & 1 & - & - & - & - \\
\hline 13 & $\begin{array}{l}\text { Indonesian-Chinese- } \\
\text { English }\end{array}$ & & - & - & - & 1 \\
\hline 14 & $\begin{array}{l}\text { Indonesian-Arabic- } \\
\text { Madurese-Javanese- } \\
\text { Malay }\end{array}$ & 1 & - & - & - & - \\
\hline 15 & $\begin{array}{l}\text { Indonesian-English- } \\
\text { German-French-Dut } \\
\text { ch-Chinese-Japanese }\end{array}$ & 1 & - & - & - & - \\
\hline
\end{tabular}

In Table 6 above, shows that Indonesian are more dominantly seen at mosque, church, Pura, and Vihara while Chinese are often found at Klenteng. Overall, Indonesian and Indonesian-English are used at the religious places. The use of national language (Indonesian) probably as a result of Law Republic of Indonesia number 24 year 2009 about flag, language, national anthem and state symbol in which Indonesian as official language in Indonesia is recommended to be used in public space. English also plays key role in multilingual society in Surabaya as International language.

The table also illustrates that signs of LL in each religious places represent their ideological and cultural identities such as Chinese temple (Klenteng) and Buddhist temples (Vihara) with Chinese language while Hindu temples (Pura) with Balinese language. That also seems to 
emerge at mosques with Arabic and churches with Latin though the two languages are the least used as shown in table 6 above.

\section{Conclusion}

Signs of multilingualism at religious places in Surabaya seems to be diverse. Languages as public signs at ten welkown religious places in Surabaya vary, i.e Indonesian, Balinese, Javanese, Madurese, Malay, English, Chinese, Arabic, Pāli language, Latin language, German, French, Dutch and Japanese. Language choice in the ten outstanding religious places represents their national, ideological and cultural identity. For example, at mosque and church, Indonesian is used at all of religious places as national identity. Meanwhile, Balinese language found at Hindu temples and Chinese language characterized at Chinese and Buddhist temples represent ideological and cultural identity.

\section{References}

Ben-Rafael, E., Shohamy, E., Amara, M. H. \& Trumper-Hecht, N. 2001. Linguistic landscape and multiculturalism: A Jewish_Arab comparative study. Unpublished research report.

Coluzzi, P. \& Kitade, R. 2015. The languages of places of worship in the Kuala Lumpur area: A study on the "religious" linguistic landscape in Malaysia. 243-267

Demografi 'demographics'. Available at www.surabaya.go.id/berita/8228-demografi. (Accessed 01 June 2018).

Ferdiyanti, N. I. 2016. Multilingualisme dalam lanskap linguistik di wilayah kota Surabaya.Unpublished research report.

Gorter, D. 2006. Linguistic landscape: A new approach to multilingualism. Clevedon: Multilingual Matters.

Landry, R., \& Bourhis, R. Y. 1997. Linguistic landscape and ethnolinguistic vitality: An empirical study. Journal of Language and Social Psychology, 16(1), 23-49.

Wardhaugh, R. \& Fuller, M. J. 2015. An introduction to sociolinguistics. UK: Blackwell.

Xia, N. \& Li, L. 2016. Studying languages in the linguistic landscape of lijiang old town. International Journal of English Linguistics. Vol 6, 105. 